Review

\title{
Natural Product Chemistry of Gorgonian Corals of Genus Junceella-Part II
}

Yang-Chang Wu ${ }^{1,2}$, Jui-Hsin Su ${ }^{3,4}$, Tai-Ting Chou ${ }^{5}$, Yin-Pin Cheng ${ }^{5}$, Ching-Feng Weng ${ }^{3,6}$, Chia-Hung Lee ${ }^{3,6}$, Lee-Shing Fang ${ }^{7}$, Wei-Hsien Wang ${ }^{4,8,9}$, Jan-Jung Li ${ }^{4}$, Mei-Chin Lu ${ }^{3,4}$, Jimmy Kuo ${ }^{3,4}$, Jyh-Horng Sheu ${ }^{8,9, *}$ and Ping-Jyun Sung ${ }^{3,4,6,8,9, *}$

1 Graduate Institute of Integrated Medicine, College of Chinese Medicine, China Medical University, Taichung 404, Taiwan; E-Mail: yachwu@mail.cmu.edu.tw

2 Natural Medicinal Products Research Center and Center for Molecular Medicine, China Medical University Hospital, Taichung 404, Taiwan

3 Institute of Marine Biotechnology, National Dong Hwa University, Pingtung 944, Taiwan; E-Mails: x2219@nmmba.gov.tw (J.-H.S.); cfweng@mail.ndhu.edu.tw (C.-F.W.); chlee016@mail.ndhu.edu.tw (C.-H.L.); jinx6609@nmmba.gov.tw (M.-C.L.); jimmy@nmmba.gov.tw (J.K.)

4 National Museum of Marine Biology and Aquarium, Pingtung 944, Taiwan; E-Mails:whw@nmmba.gov.tw (W.-H.W.); jj@nmmba.gov.tw (J.-J.L.)

5 Uni-President Biotech Co., LTD., No. 31, Gongye 2nd Rd., Annan District, Tainan 709, Taiwan; E-Mails: tong.xin@msa.hinet.net (T.-T.C.); pin@unibiotech.com.tw (Y.-P.C.)

6 Department of Life Science and Institute of Biotechnology, National Dong Hwa University, Hualien 974, Taiwan

7 Department of Sport, Health and Leisure, Cheng Shiu University, Kaohsiung 833, Taiwan; E-Mail: 1sfang@csu.edu.tw

8 Department of Marine Biotechnology and Resources, National Sun Yat-sen University, Kaohsiung 804, Taiwan

9 Division of Marine Biotechnology, Asia-Pacific Ocean Research Center, National Sun Yat-sen University, Kaohsiung 804, Taiwan

* Authors to whom correspondence should be addressed; E-Mails: sheu@mail.nsysu.edu.tw (J.-H.S.); pjsung@nmmba.gov.tw (P.-J.S.); Tel.: +886-7-525-2000 (ext. 5030) (J.-H.S.); +886-8-882-5037 (P.-J.S.); Fax: +886-7-525-5020 (J.-H.S.); +886-8-882-5087 (P.-J.S.).

Received: 10 November 2011; in revised form: 6 December 2011 / Accepted: 15 December 2011 / Published: 19 December 2011

Abstract: The structures, names, bioactivities, and references of 81 new secondary metabolites obtained from gorgonian corals belonging to the genus Junceella are described 
in this review. All compounds mentioned in this review were obtained from sea whip gorgonian corals Junceella fragilis and Junceella juncea, collected from the tropical and subtropical Indo-Pacific Ocean.

Keywords: Junceella; gorgonian; briarane; Indo-Pacific Ocean; South China Sea

\section{Introduction}

This review describes 81 new natural products from gorgonian corals belonging to the genus Junceella (phylum Cnidaria, class Anthozoa, order Gorgonacea, family Ellisellidae) [1-4]. Extending from a previous review in 2004 [5], this review describes compounds reported from November 2003 to September 2011 and provides structures, names, bioactivities and references for all compounds in tabular form.

\section{Natural Products from Gorgonian Corals Belonging to the Genus Junceella}

\subsection{Junceella fragilis}

Two new chlorinated briarane-type diterpenoids (3,8-cyclized cembranoids), (-)-2-deacetyl-junceellin (1) and (-)-3-deacetyljunceellin (2) (Table 1), along with five known briaranes, junceellin, praelolide, and junceellolides A, B and D, were isolated from the gorgonian J. fragilis, collected at the Pass Reef of Madang, Papua New Guinea [6]. The absolute stereochemistry of (-)-3-deacetyljunceellin (2) was determined by the application of a new method using a combination of proton chemical shifts and molecular dynamic calculation.

Table 1. The new natural products from Junceella fragilis-I.

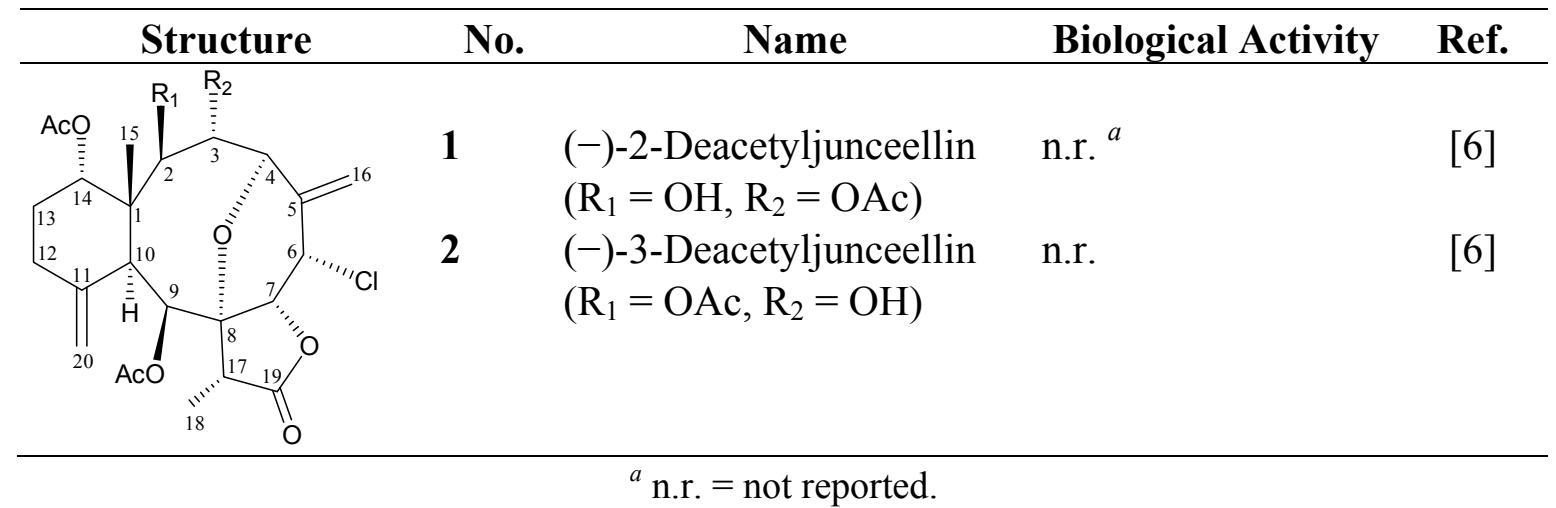

During the past 30 years, a series of interesting and bioactive natural products has been isolated from various marine invertebrates collected off the South China Sea [7,8]. Five new briaranes, junceellonoids A-E (3-7) (Table 2) [9,10], eight known briaranes, junceellins $\mathrm{A}$ and B, junceellolides A-D, umbraculolide $\mathrm{A}$ and praelolide, along with three known steroids, $24 \alpha$-methylcholest-7,22-dien-3 $\beta, 5 \alpha, 6 \beta$-triol, cholestan-3-ol and cholesterol, were isolated from 
J. fragilis inhabiting the South China Sea [9-12]. Junceellonoids C (5) and D (6) exhibited cytotoxicity toward human breast carcinoma MDA-MB-231 and MCF-7 cells [10].

Table 2. The new natural products from Junceella fragilis-II.

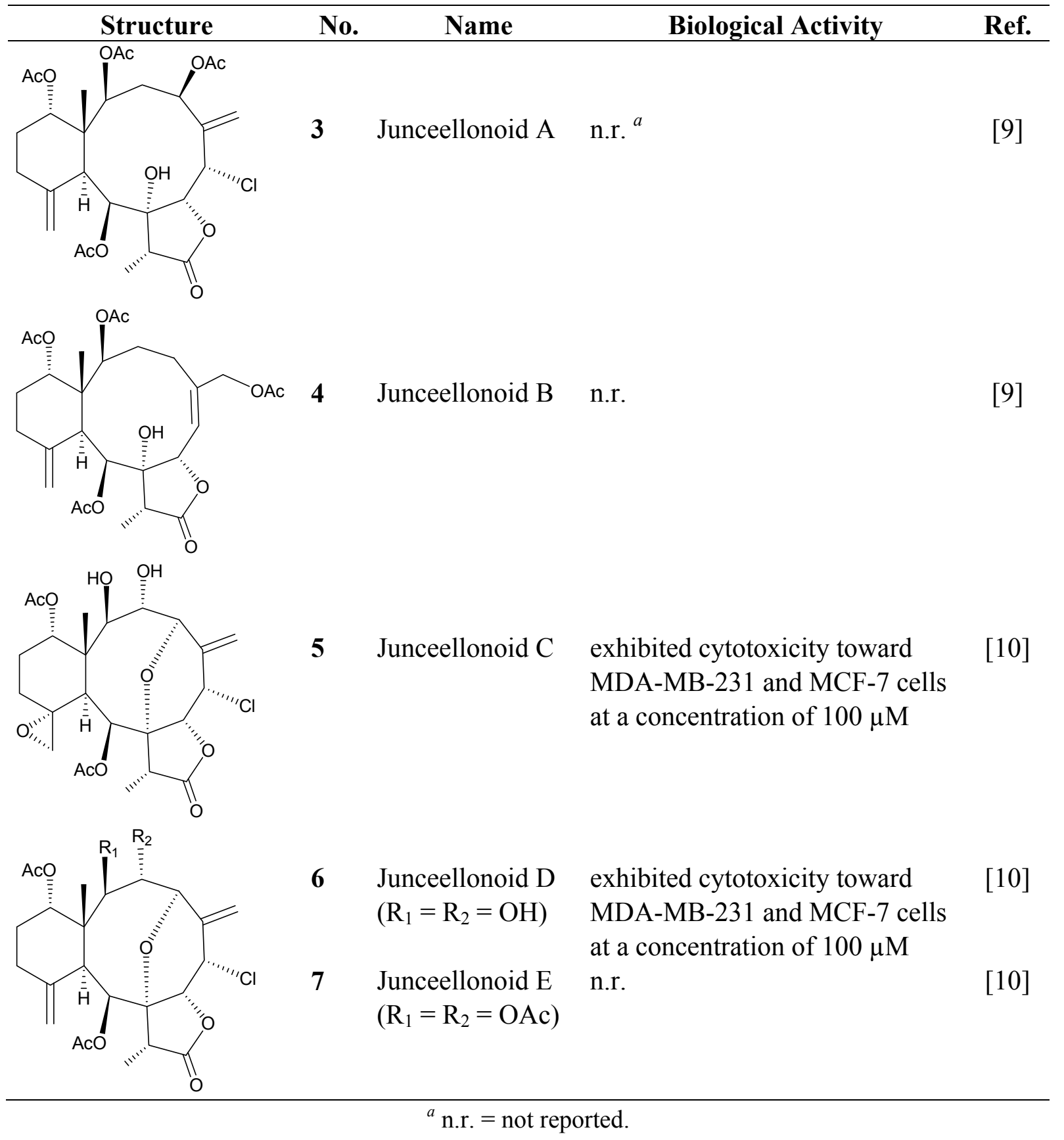

In continuing research on the new substances obtained from gorgonian corals distributed in the waters of Taiwan at the intersection of the Kuroshio current and the South China Sea surface current, the gorgonian $J$. fragilis was studied to examine the properties of its organic extract. Thirty-one new briaranes, 9-O-deacetylumbraculolide A (8) [13], junceellolides H-L (9-13) [14-16], fragilides A-J (14-23) [17-24] and frajunolides A-O (24-38) [25-27] (Table 3); 16 known briaranes, prarelolide $[14,26,28]$, junceellin A $[12,14,26,28], \quad(1 R, 2 R, 5 Z, 7 R, 8 S, 9 R, 10 R, 12 R, 14 R, 17 S)-2$, 14-diacetoxy-8,17-epoxide-9,12-dihydroxybriara-5,11(20)-dien-19-one $\quad[15], \quad(-)-11 \beta, 20 \beta$-epoxy-4deacetoxyjunceellolide D [16,25,26,29], junceellonoid D [22], juncins Y, Z and ZI [22,26], (+)-11ß, 
20ß-epoxyjunceellolide D [23,29], junceellolides A-E and K [25,26], and umbraculolide A [25,26]; and three known steroids, ergosterol peroxide [26], deoxycholic acid 3,12-diacetate, and deoxycholic acid 3,12-diacetate methyl ester [30], were isolated from $J$. fragilis collected off the waters of Taiwan. The structure, including the absolute configuration, of junceellolide $J$ (11) was confirmed by single-crystal X-ray diffraction analysis and chemical conversion [16]. Fragilide A (14) was the first briarane derivative found to possess a 6-hydroxy group [17]. The geometry of the $\Delta^{3,5(16)}$-butadiene system in fragilide B (15) was found to be of an $s$-cis form [18]. The ${ }^{13} \mathrm{C}$ NMR data for the known briaranes praelolide and junceellin were reassigned by 2D NMR experiments [14].

Table 3. The new natural products from Junceella fragilis-III.

Ref.
(13)


Table 3. Cont.

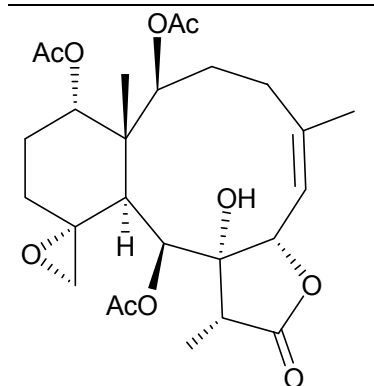

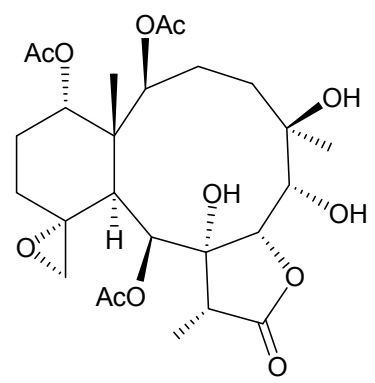

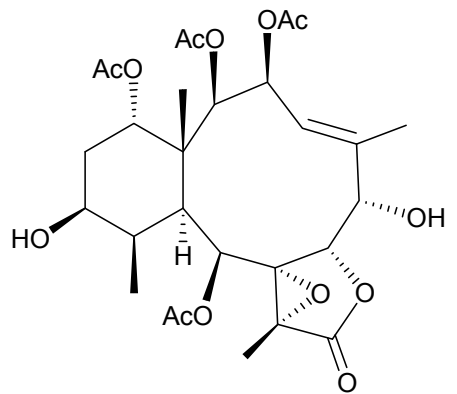

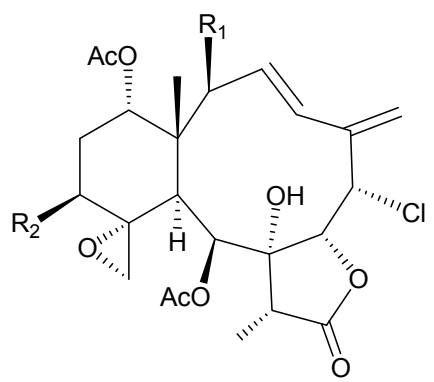

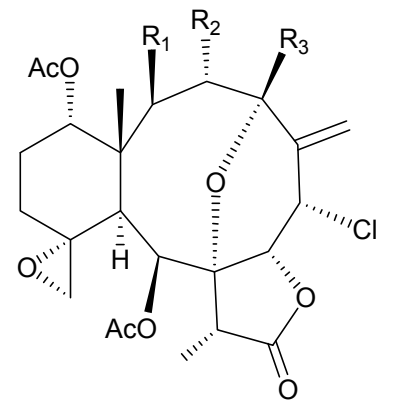

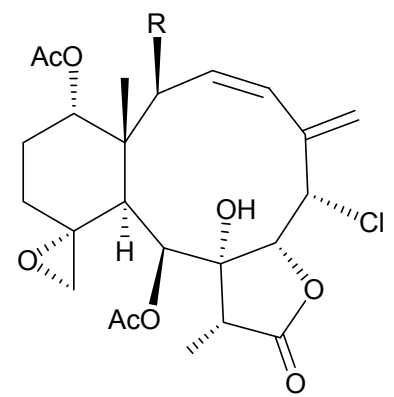

12 Junceellolide $\mathrm{K}$

weakly anti-inflammatory
13 Junceellolide L

14 Fragilide A not active in anti-inflammatory bioassay

15 Fragilide $\mathrm{B}$ weakly anti-inflammatory $\left(\mathrm{R}_{1}=\mathrm{OC}(\mathrm{O}) \mathrm{CH}_{2} \mathrm{CH}_{3}, \mathrm{R}_{2}=\mathrm{H}\right)$

20 Fragilide $\mathrm{G}$ $\left(\mathrm{R}_{1}=\mathrm{R}_{2}=\mathrm{OAc}\right)$ not active in cytotoxicity testing with DLD-1 and CCRF-CEM cells

weakly anti-inflammatory $\left(\mathrm{R}_{1}=\mathrm{OCOCH}_{2} \mathrm{CH}_{3}, \mathrm{R}_{2}=\mathrm{H}\right.$, $\left.\mathrm{R}_{3}=\mathrm{OH}\right)$

23 Fragilide $\mathrm{J}$ weakly anti-inflammatory $\left(\mathrm{R}_{1}=\mathrm{OH}, \mathrm{R}_{2}=\mathrm{OAc}, \mathrm{R}_{3}=\mathrm{H}\right)$

17 Fragilide $\mathrm{D}$ (= Frajunolide $\mathrm{G}$ ) n.r.

$\left(\mathrm{R}=\mathrm{OC}(\mathrm{O}) \mathrm{CH}_{2} \mathrm{OC}(\mathrm{O})\right.$

$\left.\mathrm{CH}_{2} \mathrm{CH}\left(\mathrm{CH}_{3}\right)_{2}\right)$ 
Table 3. Cont.

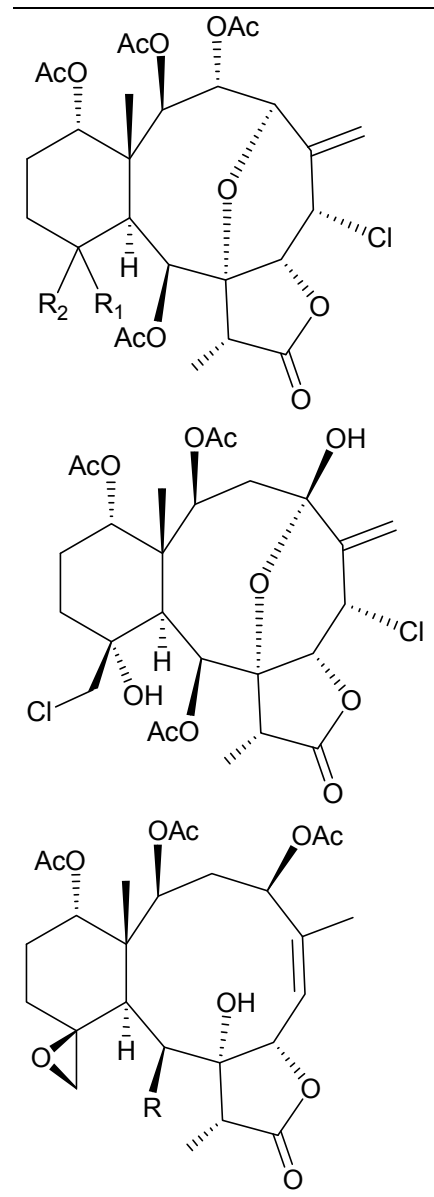

18 Fragilide $\mathrm{E}$

weakly anti-inflammatory

$\left(\mathrm{R}_{1}=\beta-\mathrm{OH}, \mathrm{R}_{2}=\alpha-\mathrm{CH}_{2} \mathrm{OAc}\right)$

19 Fragilide $\mathrm{F}$

not active in cytotoxicity

$\left(\mathrm{R}_{1}=\alpha-\mathrm{OH}, \mathrm{R}_{2}=\beta-\mathrm{CH}_{2} \mathrm{Cl}\right)$

testing with DLD-1 and

CCRF-CEM cells

21 Fragilide $\mathrm{H}$

not active in cytotoxicity testing with P-388D1, DLD-1, HL-60 and CCRF-CEM cells ${ }^{b}$

22 Fragilide I $\left(\mathrm{R}=\mathrm{OC}(\mathrm{O}) \mathrm{CH}_{2} \mathrm{CH}\left(\mathrm{CH}_{3}\right)_{2}\right)$

24 Frajunolide $\mathrm{A}$ $\left(\mathrm{R}_{1}=\alpha-\mathrm{OAc}, \mathrm{R}_{2}=\mathrm{H}\right)$

25 Frajunolide $\mathrm{B}$ $\left(\mathrm{R}_{1}=\alpha-\mathrm{OAc}, \mathrm{R}_{2}=\mathrm{OAc}\right)$

28 Frajunolide $\mathrm{E}$ $\left(\mathrm{R}_{1}=\mathrm{H}, \mathrm{R}_{2}=\mathrm{OAc}\right)$

33 Frajunolide $\mathrm{J}$ $\left(\mathrm{R}_{1}=\alpha-\mathrm{OC}(\mathrm{O}) \mathrm{Et}, \mathrm{R}_{2}=\mathrm{H}\right)$

35 Frajunolide $\mathrm{L}$ $\left(\mathrm{R}_{1}=\beta-\mathrm{OAc}, \mathrm{R}_{2}=\mathrm{H}\right)$

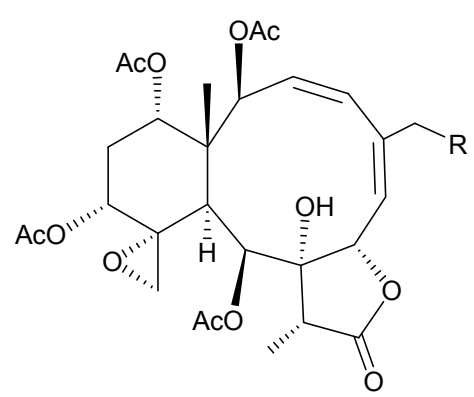

26 Frajunolide $\mathrm{C}$ $(\mathrm{R}=\mathrm{Cl})$

27 Frajunolide D $(\mathrm{R}=\mathrm{OAc})$ not active in cytotoxicity testing with P-388D1, DLD-1, HL-60 and CCRF-CEM cells

weakly anti-inflammatory

weakly anti-inflammatory

frajunolides $\mathrm{E}, \mathrm{J}$ and $\mathrm{L}$ were weakly anti-inflammatory frajunolides $\mathrm{E}$ and $\mathrm{J}$ were not active in cytotoxicity testing with Hep2, Doay, WiDr and Hela cells ${ }^{b}$ weakly anti-inflammatory

not active in anti-inflammatory bioassay 
Table 3. Cont.

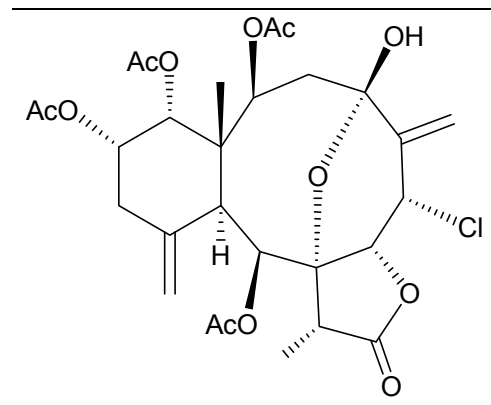

29 Frajunolide F

weakly anti-inflammatory

not active in cytotoxicity

testing with Hep2, Doay,

WiDr and Hela cells

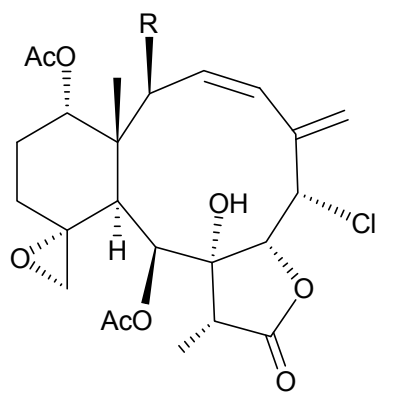

30 Frajunolide $\mathrm{G}$ (= Fragilide $\mathrm{D})$ not active in $\left(\mathrm{R}=\mathrm{OC}(\mathrm{O}) \mathrm{CH}_{2} \mathrm{OC}(\mathrm{O})\right.$ $\left.\mathrm{CH}_{2} \mathrm{CH}\left(\mathrm{CH}_{3}\right)_{2}\right)$

anti-inflammatory bioassay not active in cytotoxicity testing with Hep2, Doay, WiDr and Hela cells

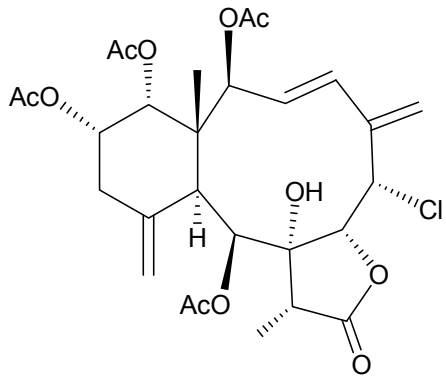

31 Frajunolide $\mathrm{H}$

not active in

anti-inflammatory bioassay not active in cytotoxicity testing with Hep2, Doay, WiDr and Hela cells

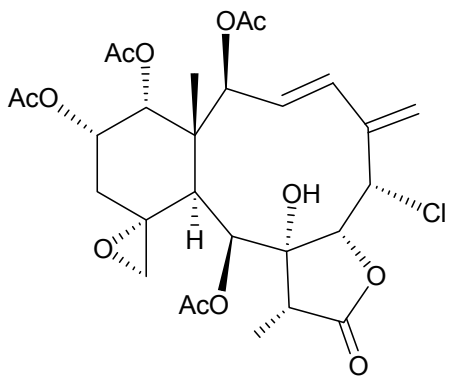

32 Frajunolide I

weakly anti-inflammatory

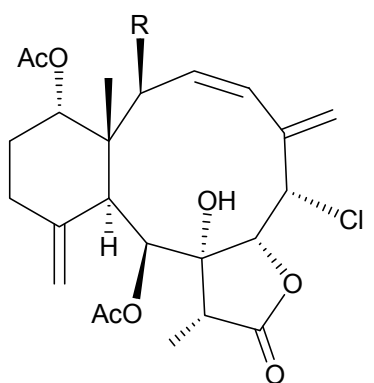

34 Frajunolide $\mathrm{K}$ $\left(\mathrm{R}=\mathrm{OC}(\mathrm{O}) \mathrm{CH}_{2} \mathrm{OC}(\mathrm{O})\right.$ $\left.\mathrm{CH}_{2} \mathrm{CH}\left(\mathrm{CH}_{3}\right)_{2}\right)$ not active in cytotoxicity testing with Hep2, Doay, WiDr and Hela cells 
Table 3. Cont.

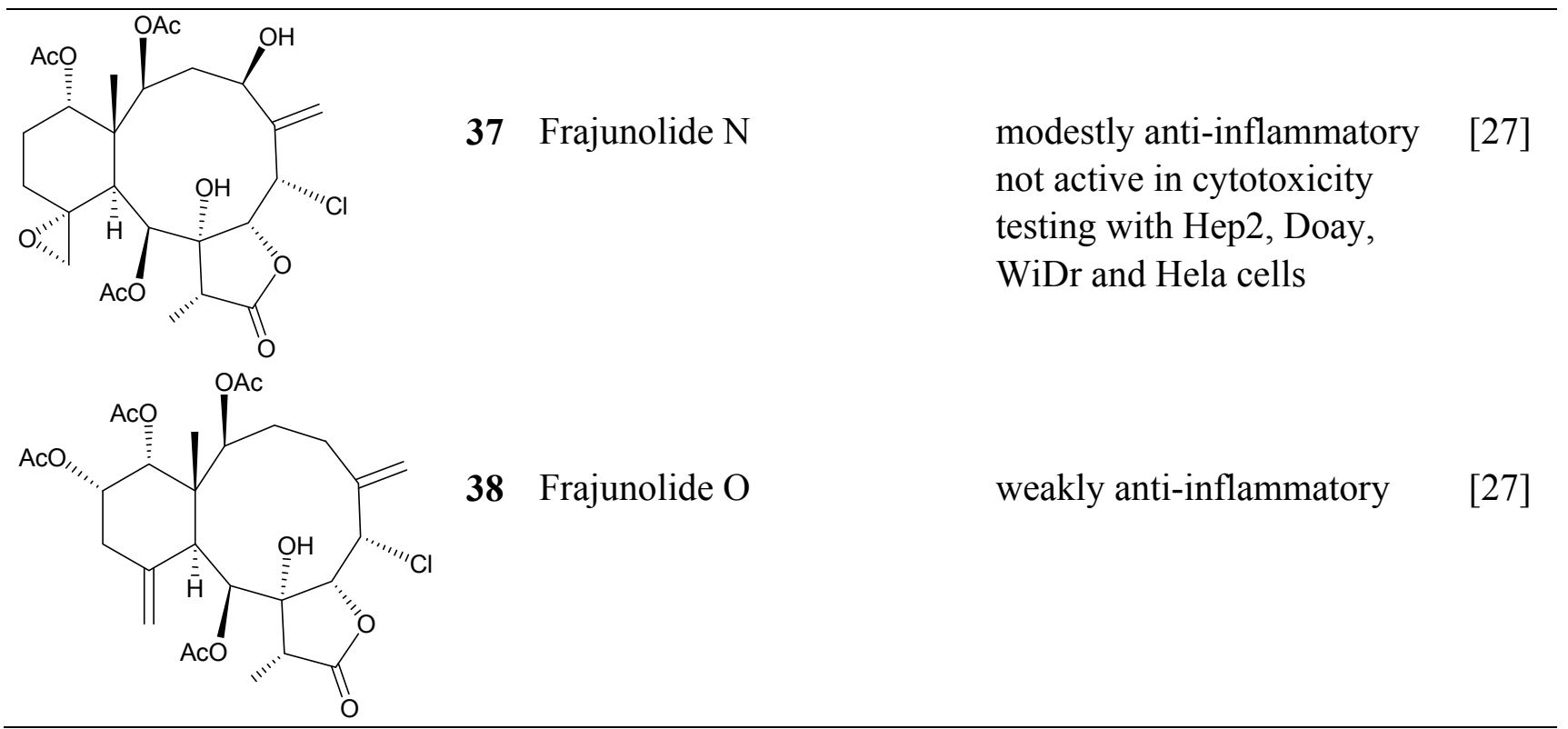

\begin{abstract}
${ }^{a}$ n.r. $=$ not reported; ${ }^{b}$ P388D1 (mouse lymphoid neoplasm), DLD-1 (human colon adenocarcinoma), IMR-32 (human neuroblastoma), RPMI 7951 (human malignant melanoma), CCRF-CEM (human T-cell acute lymphoblastic leukemia), HL-60 (human promyelocytic leukemia), Hep2 (human liver carcinoma), Doay (medulloblastoma), WiDr (human colon adenocarcinoma), Hela (human cervical epitheloid carcinoma).
\end{abstract}

In order to determine the stereochemistry of briaranes possessing an exocyclic 11,20-epoxy group, the ${ }^{13} \mathrm{C}$ NMR data of the exocyclic 11,20-epoxy groups have been summarized; these appeared at $\delta_{\mathrm{C}} 62-63$ and 58-60 ppm, respectively, when the epoxy group existed in the $11 S^{*}$ form and led the cyclohexane rings to exhibit a twist boat conformation. If the epoxy group was in an $11 R^{*}$ configuration, the ${ }^{13} \mathrm{C}$ NMR data for $\mathrm{C}-11$ and $\mathrm{C}-20$ appeared at $\delta_{\mathrm{C}} 55-61$ and 47-52 ppm, respectively, and the cyclohexane rings were in a chair conformation [16]. The 11,20-epoxybriaranes were only obtained from gorgonian corals belonging to the Ellisellidae family, and, thus compounds of this type could be a chemical marker for gorgonian corals belonging to the Ellisellidae family [31].

From the characteristics of the chemical shifts, it was shown that the briarane derivatives contained an exocyclic double bond between C-11/12. The proton chemical shifts were summed up for the olefin protons $\mathrm{H}_{2}-20$; these appear at $\delta_{\mathrm{H}} 4.95-5.30$ and 4.85-5.15 ppm, respectively, when the cyclohexane rings are in a twist boat conformation. Likewise, the ${ }^{1} \mathrm{H}$ NMR data for $\mathrm{H}_{2}-20$ appear at $\delta_{\mathrm{H}} 4.95-5.10$ and 4.40-4.75, if the cyclohexane rings were found to exist in a chair conformation [22].

Symbiotic algae (zooxanthella) exist throughout the life cycle of $J$. fragilis, while $J$. juncea is a gorgonian coral free of zooxanthellae [32]. Two known chlorine-containing briaranes, junceellin and praelolide, were isolated in the same proportions from both J. fragilis and J. juncea, and this observation suggests that junceellin and praelolide could be chemical markers that enable one to infer that the briarane-type compounds are originally synthesized by the host corals [28] and are not produced by their zooxanthella. 
In biological activity experiments, the new briaranes, junceellolide $\mathrm{K}$ (12) [16], fragilides $\mathrm{B}, \mathrm{C}$, $\mathrm{E}$ and $\mathrm{J}(\mathbf{1 5}, \mathbf{1 6}, \mathbf{1 8}, \mathbf{2 3})[18,19,21,24]$, frajunolides A-C (24-26), E (28), F (29), I (32), J (33), L-O

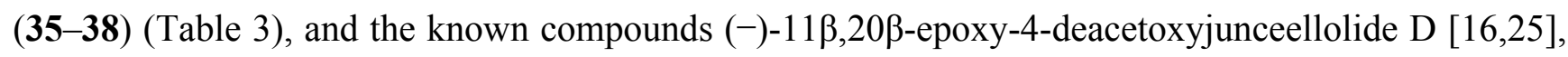
junceellolide E [25] and umbraculolide A [25], displayed anti-inflammatory activity [33]. Juncin Z was found to exhibit cytotoxicity toward CCRF-CEM cells [22].

\subsection{Junceella juncea}

Five new steroidal glycosides, 4'- $O$-acetyl-3- $O$-[ $\beta$-D-arabino-pyranosyl-oxy]-cholest-5-ene-3 $\beta, 19$-diol (39) [34] and junceellosides A-D (40-43) [35], and a new glycerol, 1,2-O-[2'-hydroxyoctadecyl]-glycerol (44) [34] (Table 4) along with various known metabolites, including four sterols, $24 \alpha$-methylcholest-7,

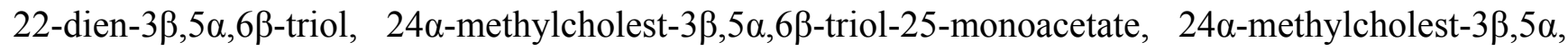

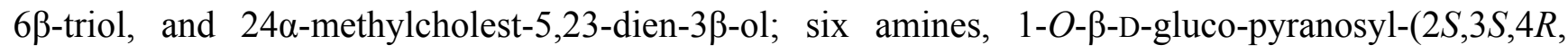
$8 Z)-2-N$-(2'-hydroxypalmitoyl)-octadecasphinga-8-ene, (2S,3R)-2- $N$-palmitoyl-octadecasphinga, (2S, $3 R, 4 E)$-2- $N$-palmitoyloctadecasphinga-4-ene, thymine, uracil, and adenosine; and batyl alcohol, were isolated from the gorgonian coral J. juncea, collected off the South China Sea in 2004-2005 [34,35].

Table 4. The new natural products from Junceella juncea-IV.

\begin{tabular}{lll}
\hline & \multicolumn{1}{c}{ Name } & Ref. \\
\hline
\end{tabular}

In addition, 14 new briarane derivatives, juncins O-Q (45-47) [36], R-ZI (48-57) [37], and ZII (58) [38] (Table 5), along with eight known briaranes, praelolide, junceellin, gemmacolides A-C

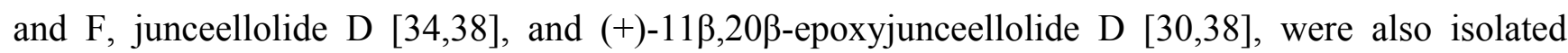
from J. juncea. 
Table 5. The new natural products from Junceella juncea-V.

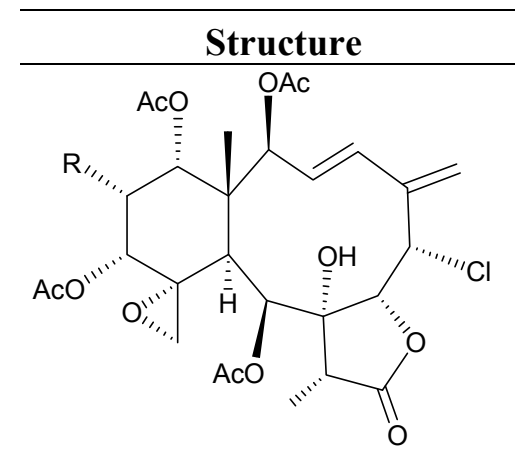

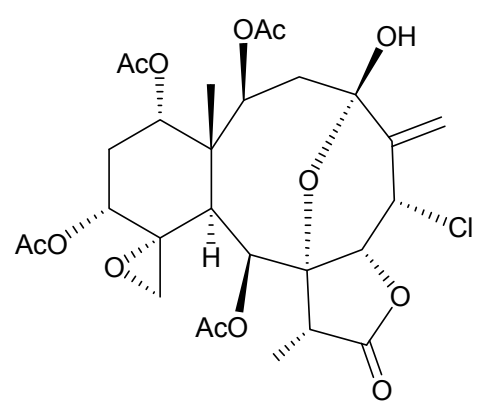

46 Juncin $P$ \begin{tabular}{ll} 
No. & \multicolumn{1}{c}{ Name } \\
\hline 45 & Juncin $\mathrm{O}$ \\
& $(\mathrm{R}=\mathrm{OC}(\mathrm{O})$ \\
& $\left.\mathrm{CH}_{2} \mathrm{CH}\left(\mathrm{CH}_{3}\right)_{2}\right)$
\end{tabular} activity $(90.7,69.0,46.5 \%)$ toward the second-instar larvae of Spodoptera litura at a concentration of $500 \mu \mathrm{g} / \mathrm{mL}$ juncins $\mathrm{O}-\mathrm{Q}$ and $\mathrm{ZII}$ were not active in cytotoxicity testing with K562, A549, Hela and Hep2 cells ${ }^{a}$ medium cytotoxicity (cell mortality: $8.7 \%$ in $24 \mathrm{~h}$ and $11.9 \%$ in $48 \mathrm{~h}$ ) toward the second-instar larvae of $S$. litura at a concentration of $100 \mu \mathrm{g} / \mathrm{mL}$

medium cytotoxicity (cell mortality: $25.3 \%$ in $24 \mathrm{~h}$ and $29.7 \%$ in $48 \mathrm{~h}$ ) toward the second-instar larvae of $S$. litura at a concentration of $100 \mu \mathrm{g} / \mathrm{mL}$

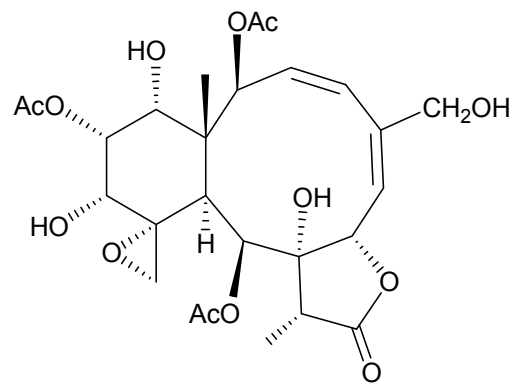

47 Juncin Q

medium cytotoxicity (cell mortality: $31.3 \%$ in $24 \mathrm{~h}$ and $44.0 \%$ in $48 \mathrm{~h}$ ) toward the second-instar larvae of $S$. litura at a concentration of $100 \mu \mathrm{g} / \mathrm{mL}$

54 Juncin X

55 Juncin $\mathrm{Y}$ $\left(\mathrm{R}=\mathrm{CH}_{2} \mathrm{OAc}\right)$

56 Juncin $\mathrm{Z}$ $\left(\mathrm{R}=\mathrm{CO}(\mathrm{O}) \mathrm{CH}_{3}\right)$ 
Table 5. Cont.

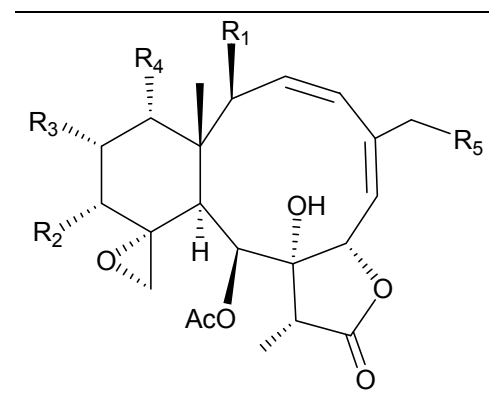

48 Juncin $\mathrm{R}$

$\left(\mathrm{R}_{1}=\mathrm{R}_{2}=\mathrm{R}_{3}=\mathrm{OAc}\right.$,

$\mathrm{R}_{4}=\mathrm{OC}(\mathrm{O}) \mathrm{CH}_{2} \mathrm{CH}\left(\mathrm{CH}_{3}\right)_{2}$,

$\mathrm{R}_{5}=\mathrm{Cl}$ )

49 Juncin $\mathrm{S}$

$\left(\mathrm{R}_{1}=\mathrm{R}_{3}=\mathrm{R}_{4}=\mathrm{OAc}\right.$,

$\mathrm{R}_{2}=\mathrm{OC}(\mathrm{O}) \mathrm{CH}_{2} \mathrm{CH}\left(\mathrm{CH}_{3}\right)_{2}$,

$\mathrm{R}_{5}=\mathrm{Cl}$ )

50 Juncin $T$

$\left(\mathrm{R}_{1}=\mathrm{OC}(\mathrm{O}) \mathrm{CH}_{2} \mathrm{OC}(\mathrm{O})\right.$

$\left(\mathrm{CH}_{2}\right)_{2} \mathrm{CH}\left(\mathrm{CH}_{3}\right)_{2}$,

$\mathrm{R}_{2}=\mathrm{R}_{3}=\mathrm{R}_{4}=\mathrm{OAc}$,

$\left.\mathrm{R}_{5}=\mathrm{OH}\right)$

51 Juncin $\mathrm{U}$

$\left(\mathrm{R}_{1}=\mathrm{R}_{2}=\mathrm{R}_{4}=\mathrm{OAc}\right.$,

$\mathrm{R}_{3}=\mathrm{OC}(\mathrm{O}) \mathrm{CH}_{2} \mathrm{CH}\left(\mathrm{CH}_{3}\right)_{2}$,

$\left.\mathrm{R}_{5}=\mathrm{OCH}_{3}\right)$

52 Juncin $\mathrm{V}$

$\left(\mathrm{R}_{1}=\mathrm{R}_{3}=\mathrm{OAc}\right.$,

$\mathrm{R}_{2}=\mathrm{R}_{4}=\mathrm{OH}$,

$\mathrm{R}_{5}=\mathrm{OCH}_{3}$ )

53 Juncin W

$\left(\mathrm{R}_{1}=\mathrm{R}_{3}=\mathrm{R}_{5}=\mathrm{OAc}\right.$,

$\mathrm{R}_{2}=\mathrm{R}_{4}=\mathrm{OH}$ )

57 Juncin ZI

58 Juncin ZII

$\left(\mathrm{R}=\mathrm{OC}(\mathrm{O})\left(\mathrm{CH}_{2}\right)_{2} \mathrm{CH}\left(\mathrm{CH}_{3}\right)_{2}\right)$ juncins R-ZII (48-58) exhibited

[37]

antifouling activity toward the

barnacle Balanus amphitrite

larvae $\left(\mathrm{EC}_{50}=0.004,0.3,2.7\right.$,

$1.6,3.8,21.1,0.004,0.1,1.5,0.5$

and $0.004 \mu \mathrm{g} / \mathrm{mL}$ )
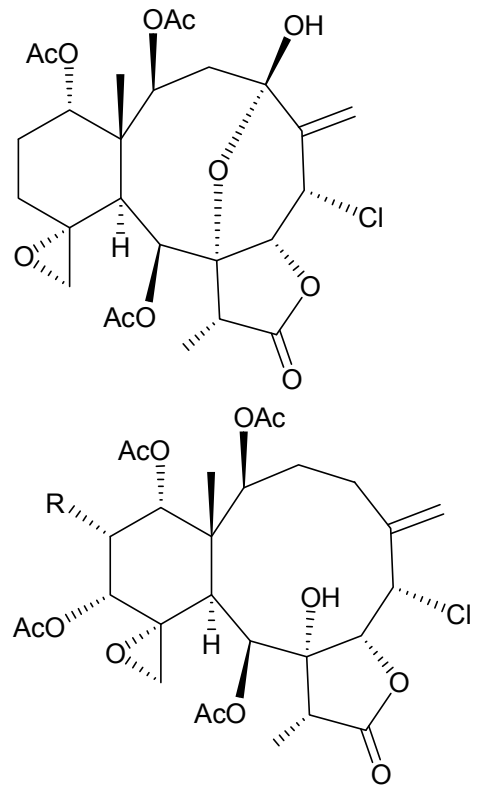

medium antifeedant activity

(84.5\%) toward the second-instar larvae of Spodoptera litura at a concentration of $500 \mu \mathrm{g} / \mathrm{mL}$ medium cytotoxicity (cell mortality: $20.5 \%$ in $24 \mathrm{~h}$ and $43.2 \%$ in $48 \mathrm{~h}$ ) toward the second-instar larvae of $S$. litura at a concentration of $100 \mu \mathrm{g} / \mathrm{mL}$

${ }^{a}$ K562 (human erythromyeloblastoid leukemia), A549 (human lung adenocarcinoma), Hela (human cervical epitheloid carcinoma), Hep2 (human liver carcinoma). 
In biological activity testing, juncins R-ZII (48-58) showed potent antifouling activities against the larval settlement of barnacle Balanus amphitrite at a nontoxic concentration (Table 5), and the structure-activity relationships have been discussed [37,38]. The potency of these compounds to inhibit larval settlement was increased when the C-16 exocyclic oxymethylene was substituted by a methylene-bearing chlorine atom and decreased when the exocyclic oxymethylene C-16 was esterified or the acetoxymethylene $\mathrm{C}-16$ was oxygenated to become an esterified group. The chain lengths of the ester moieties at C-1, C-12, C-13 and C-14 and the 11,20-epoxy group could also affect the antifouling activities [37,38].

The known briaranes, gemmacolides A, B, and junceellolide D, were also found to exhibit an antifouling activity as potent as that of juncins R-ZII [38], and these three compounds were not cytotoxic towards the K562, A549, Hela and Hep2 cells. In addition, all the known briaranes showed medium antifeedant activity toward the second-instar larvae of Spodoptera litura at a concentration of $500 \mu \mathrm{g} / \mathrm{mL}[38]$.

The gorgonian $J$. juncea collected off the Indian Ocean was proven to be a rich source of interesting natural products. The ethyl acetate extract of $J$. juncea exhibited anti-inflammatory activity at concentrations of 30-100 mg/kg body weight, while the oral median lethal dose $\left(\mathrm{LD}_{50}\right)$ for the extract in albino mice was above $1000 \mathrm{mg} / \mathrm{kg}$. The ethyl acetate extract of $J$. juncea also showed antibacterial activities toward Bacillus subtilis, B. pumilis and Escherichia coli [39]. Six new briaranes, juncins I-M (59-63) [40] and juncenolide B (64) [41], a new sphingolipid, (2R,3R,4E)-1,3-dihydroxy-2[(nonadecanoyl) amino]-octadec-4-ene (65) [42] (Table 6), along with four known briaranes, gemmacolides $\mathrm{A}-\mathrm{C}$ and juncin $\mathrm{H}$ [40], were obtained from the gorgonian coral J. juncea, collected from Tuticorin Coast of the Indian Ocean.

Table 6. The new natural products from Junceella juncea-VI.

$\begin{array}{lll}\text { Riological Activity } & \text { Ref. } \\ {[40]}\end{array}$


Table 6. Cont.

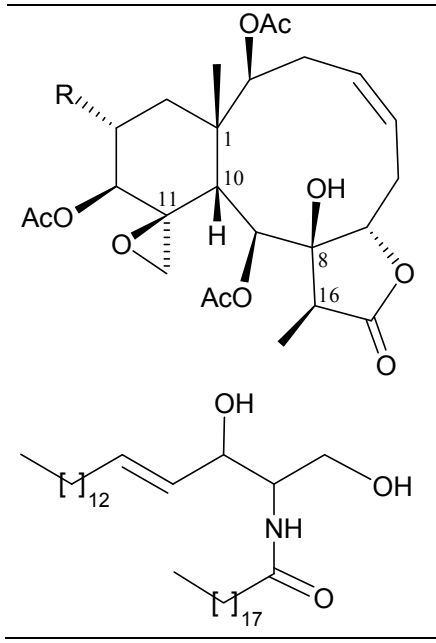

64 Juncenolide B

n.r.

$\left(\mathrm{R}=\mathrm{OCOCH}_{2} \mathrm{CH}\left(\mathrm{CH}_{3}\right)_{2}\right)$
$65 \quad(2 R, 3 R, 4 E)-1,3$-dihydroxy-2- $\quad$ n.r. [(nonadecanoyl) amino]-octadec-
4-ene

The molecular formula of juncenolide $\mathrm{B}$ was reported as $\mathrm{C}_{30} \mathrm{H}_{42} \mathrm{O}_{11}(\mathrm{M} . \mathrm{W} .=578)$, but the structure presented in the article was found to possess the molecular formula $\mathrm{C}_{30} \mathrm{H}_{42} \mathrm{O}_{12}$ (M.W. = 594). The spectral data (such as from NOESY experiments) was not sufficient to support the structure presented in the article. We therefore suggested that the structure of this compound (juncenolide B) should be reexamined [41].

Sixteen new briaranes, juncenolides E-K (66-72) [43-45], juncin N (73) [46], and junceols A-H (74-81) [20,47] (Table 7), and two known briaranes, junceellolides B and C, were isolated from the gorgonian $J$. juncea, collected off the waters of Taiwan. Juncenolide $G(\mathbf{6 8})$ is the first naturally-occurring briarane found to have an ether linkage between C-5/C-8 [44], and juncin $\mathrm{N}$ (73) is the first briarane derivative found to contain a carboxylic group [46].

Table 7. The new natural products from Junceella juncea-VII.

$\begin{array}{lll}\text { Ref. } & \text { Name } \\ \text { Juncenolide E }\end{array}$


Table 7. Cont.

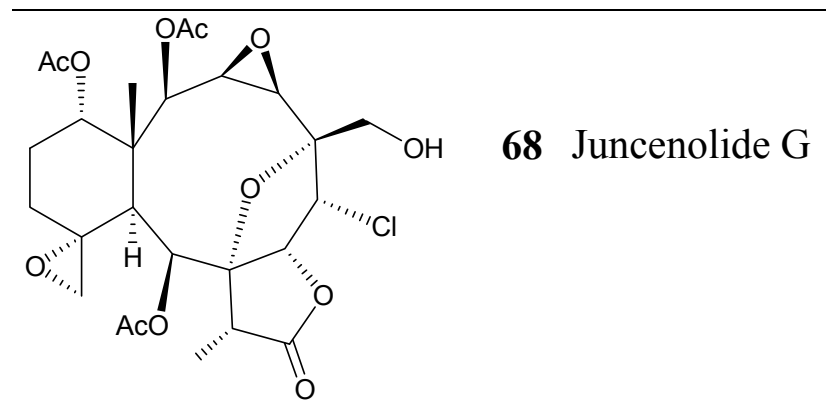

n.r.

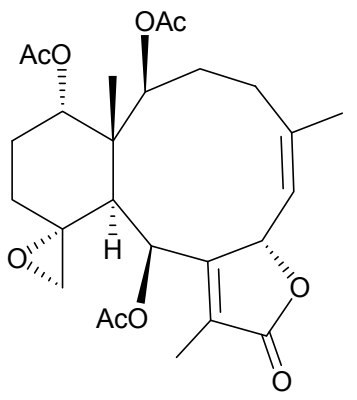

72 Juncenolide $\mathrm{K}$

weakly anti-inflammatory

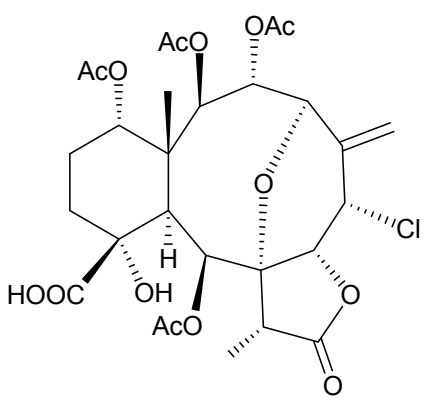

73 Juncin N

not active in cytotoxicity testing with P-388D1, DLD-1, IMR-32, RPMI 7951 and CCRF-CEM cells ${ }^{b}$

74 Junceol A significantly $\left(\mathrm{R}=\mathrm{OC}(\mathrm{O}) \mathrm{CH}_{2} \mathrm{CH}\left(\mathrm{CH}_{3}\right)_{2}\right) \quad$ anti-inflammatory

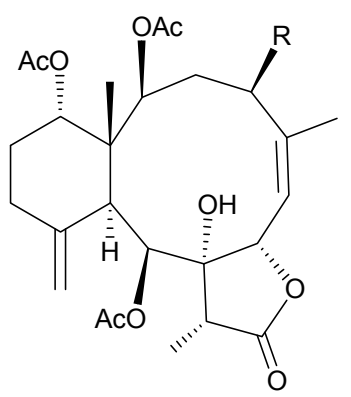

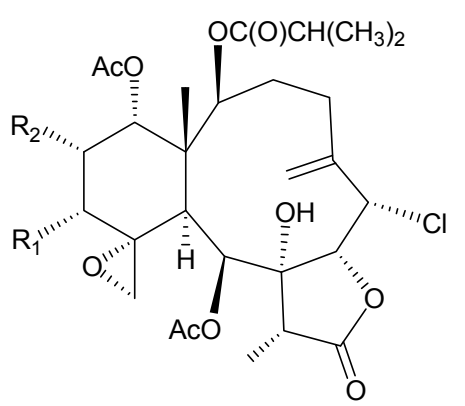

75 Junceol B

significantly

$\left(\mathrm{R}_{1}=\mathrm{OAc}\right.$,

anti-inflammatory

$\left.\mathrm{R}_{2}=\mathrm{OC}(\mathrm{O}) \mathrm{CH}_{2} \mathrm{CH}\left(\mathrm{CH}_{3}\right)_{2}\right)$

76 Junceol $\mathrm{C}$

significantly 
Table 7. Cont.

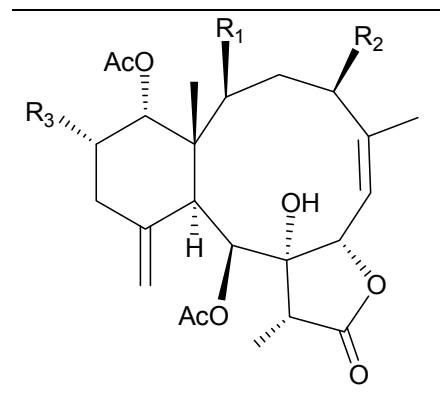

77 Junceol D

$\left(\mathrm{R}_{1}=\mathrm{OC}(\mathrm{O}) \mathrm{CH}\left(\mathrm{CH}_{3}\right)_{2}\right.$, $\mathrm{R}_{2}=\mathrm{OC}(\mathrm{O}) \mathrm{CH}_{2} \mathrm{CH}\left(\mathrm{CH}_{3}\right)_{2}$,

$\mathrm{R}_{3}=\mathrm{OAc}$ )

78 Junceol E

$\left(\mathrm{R}_{1}=\mathrm{OC}(\mathrm{O}) \mathrm{CH}\left(\mathrm{CH}_{3}\right)_{2}\right.$, $\mathrm{R}_{2}=\mathrm{OAc}, \mathrm{R}_{3}=\mathrm{H}$ )

79 Junceol F $\left(\mathrm{R}_{1}=\mathrm{OC}(\mathrm{O}) \mathrm{CH}\left(\mathrm{CH}_{3}\right) \mathrm{CH}_{2} \mathrm{CH}_{3}\right.$, $\mathrm{R}_{2}=\mathrm{OAc}, \mathrm{R}_{3}=\mathrm{H}$ ) not active in anti-inflammaory

bioassay

exhibited cytotoxicity toward

CCRF-CEM and DLD-1

$\left(\mathrm{IC}_{50}=1.3,10.0 \mu \mathrm{g} / \mathrm{mL}\right)$ cells

weakly anti-inflammatory

not active in cytotoxicity testing

with CCRF-CEM and DLD-1

$\left(\mathrm{IC}_{50}>40 \mu \mathrm{g} / \mathrm{mL}\right.$ ) cells

moderately anti-inflammatory

exhibited cytotoxicity toward

CCRF-CEM $\left(\mathrm{IC}_{50}=4.9 \mu \mathrm{g} / \mathrm{mL}\right)$ cells

weakly anti-inflammatory

exhibited cytotoxicity toward

CCRF-CEM $\left(\mathrm{IC}_{50}=4.4 \mu \mathrm{g} / \mathrm{mL}\right)$

weakly anti-inflammatory

exhibited cytotoxicity toward

CCRF-CEM and DLD-1

$\left(\mathrm{IC}_{50}=7.2,17.0 \mu \mathrm{g} / \mathrm{mL}\right)$ cells

$$
\begin{aligned}
& \left(\mathrm{R}_{1}=\mathrm{OAc}, \mathrm{R}_{2}=\mathrm{H},\right. \\
& \left.\mathrm{R}_{3}=\mathrm{OC}(\mathrm{O}) \mathrm{CH}\left(\mathrm{CH}_{3}\right)_{2}\right)
\end{aligned}
$$

${ }^{a}$ n.r. $=$ not reported. ${ }^{b}$ P388D1 (mouse lymphoid neoplasm), DLD-1 (human colon adenocarcinoma), IMR-32 (human neuroblastoma), RPMI 7951 (human malignant melanoma), CCRF-CEM (human T-cell acute lymphoblastic leukemia).

\section{Conclusions}

The chemical class distribution of the natural products obtained from the organisms Junceella fragilis and Junceella juncea compiled in this review indicates that terpenoid derivatives, particularly briarane-type diterpenoids, are the major components of the natural products isolated. Of the 81 new metabolites, 74 compounds are briarane-type diterpenoids $(91.4 \%)$. Of these briaranes, over 50\% are chlorinated briaranes $(38 / 74=51.4 \%)$, which are rarely found. Briarane-type compounds continue to attract attention owing to their structural novelty, complexity and interesting bioactivities, such as anti-inflammatory activity [48-51]. Terpenoid compounds are often present in large amounts in marine invertebrates, and as a major class represent the largest percentage of natural products isolated from marine organisms [52]. Over 500 naturally-occurring briarane derivatives have been isolated from various marine organisms [48-51]. However, owing to their structural complexity, it is difficult to obtain sufficient amounts of the bioactive metabolites, such as junceols B (75) and C (76), for further study of their potential medicinal usage. We have therefore begun to culture the potential useful gorgonian corals $J$. fragilis and $J$. juncea (Figure 1) in tanks using our highly developed aquaculture technology for extraction of natural products to establish a stable supply of bioactive materials, which also protects the natural population and habitats from over-exploitation. 
Figure 1. The cultured-type gorgonian corals Junceella fragilis (white) and Junceella juncea (red).
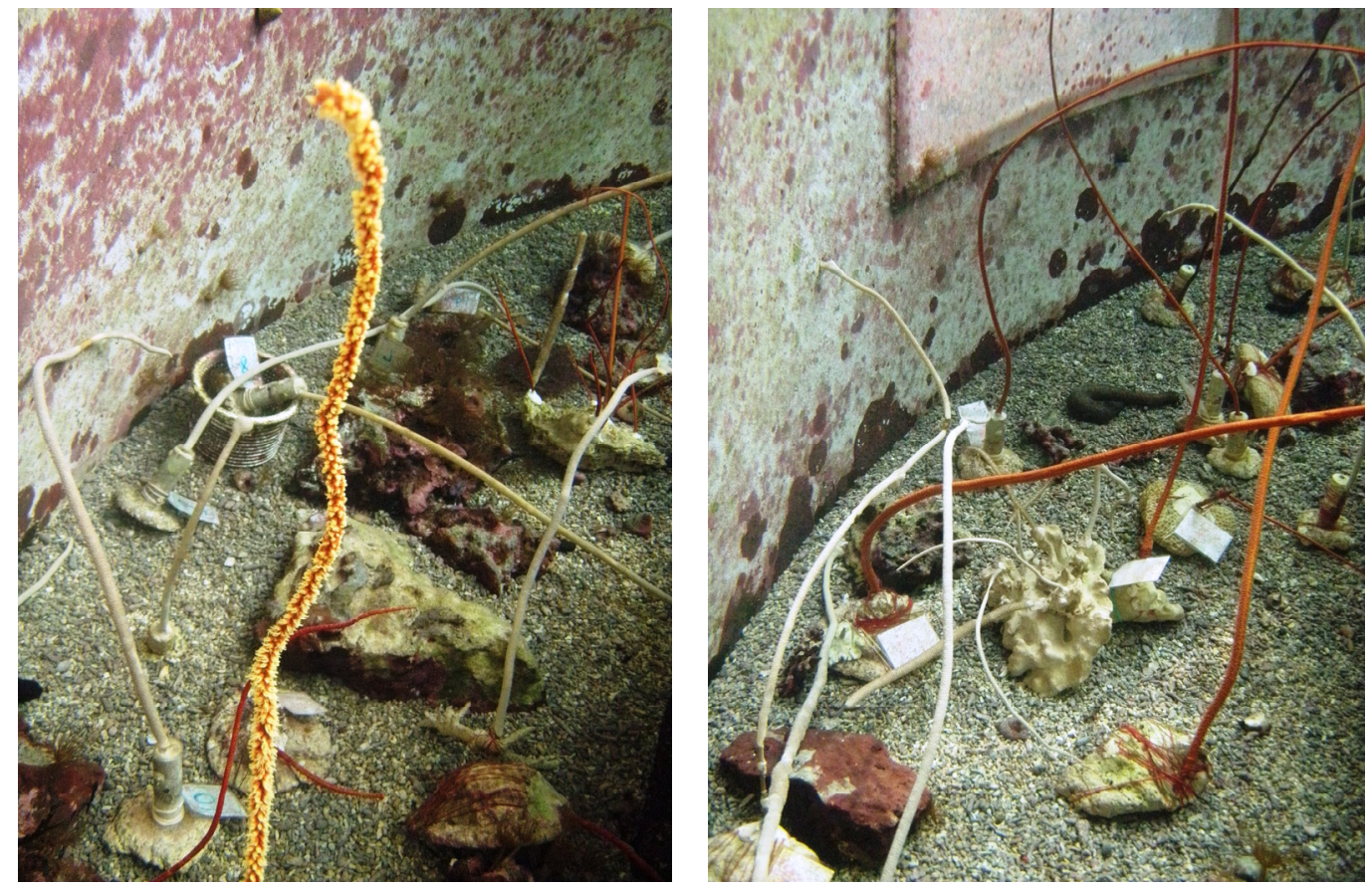

\section{Acknowledgments}

This work was supported by grants from the National Dong Hwa University; the National Museum of Marine Biology and Aquarium (Grant No. 100100101 and 100200311); the Division of Marine Biotechnology, Asia-Pacific Ocean Research Center, National Sun Yat-sen University (Grant No. 00C-0302-05); and the National Science Council, Taiwan, awarded to P.-J.S. (Grant No. NSC 100-2325-B-291-001, 99-2323-B-291-001, and 98-2320-B-291-001-MY3) and J.-H.S. (Grant No. NSC 98-2113-M-110-002-MY3).

\section{References and Notes}

1. Bayer, F.M. Key to the genera of Octocorallia exclusive of Pennatulacea (Coelenterata: Anthozoa) with diagnoses of new taxa. Proc. Biol. Soc. Wash. 1981, 94, 902-947.

2. Bayer, F.M.; Grasshoff, M. The genus group taxa of the family Ellisellidae, with clarification of the genera established by J.E. Gray (Cnidaria: Octocorallia). Senckenberg. Biol. 1994, 74, 21-45.

3. Fabricius, K.; Alderslade, P. Soft Corals and Sea Fans-A Comprehensive Guide to the Tropical Shallow-Water Genera of the Central-West Pacific, the Indian Ocean and the Red Sea, 1st ed.; Australian Institute of Marine Science: Queensland, Australia, 2001; pp. 62, 230-231.

4. Chen, C.-C.; Chang, K.-H. Gorgonacea (Coelenterata: Anthozoa: Octocorallia) of Southern Taiwan. Bull. Inst. Zool. Acad. Sin. 1991, 30, 149-182.

5. Sung, P.-J.; Gwo, H.-H.; Fan, T.-Y.; Li, J.-J.; Dong, J.; Han, C.-C.; Wu, S.-L.; Fang, L.-S. Natural product chemistry of gorgonian corals of the genus Junceella. Biochem. Syst. Ecol. 2004, 32, 185-196. 
6. Kubota, N.K.; Kobayashi, Y.; Iwamoto, H.; Fukazawa, Y.; Uchio, Y. Two new halogenated briarane diterpenes from the Papuan gorgonian coral Junceella fragilis. Bull. Chem. Soc. Jpn. 2006, 79, 634-636.

7. Zhang, W.; Guo, Y.-W.; Gu, Y. Secondary metabolites from the South China Sea invertebrates: Chemistry and biological activity. Curr. Med. Chem. 2006, 13, 2041-2090.

8. Shao, C.-L.; Fu, X.-M.; Wang, C.-Y.; Han, L.; Liu, X.; Fang, Y.-C.; Li, G.-Q.; Zeng, X.-Q.; Liu, G.-X.; Guan, H.-S. Investigation on the status of coral reef resources and medicinal research in China III. Status of folk medicinal usage and medicinal research. Zhongguo Haiyang Daxue Xuebao (Ziran Kexueban) 2009, 39, 691-698.

9. Zhang, W.; Guo, Y.-W.; Mollo, E.; Cimino, G. Junceellonoids A and B, two new briarane diterpenoids from the Chinese gorgonian Junceella fragilis Ridley. Helv. Chim. Acta 2004, 87, 2341-2345.

10. Qi, S.-H.; Zhang, S.; Wen, Y.-M.; Xiao, Z.-H.; Li, Q.-X. New briaranes from the South China Sea gorgonian Junceella fragilis. Helv. Chim. Acta 2005, 88, 2349-2354.

11. Wen, Y.-M.; Qi, S.-H.; Zhang, S. Briarane diterpenes and steroids from the South China Sea gorgonian Junceella fragilis. Nat. Prod. Res. Dev. 2006, 18, 234-237.

12. Lin, Y.; Long, K. Studies of the chemical constituents of the Chinese gorgonia (IV)-Junceellin, a new chlorine-containing diterpenoid from Junceella squamata. Zhongshan Daxue Xuebao (Ziran Kexueban) 1983, 22, 46-51.

13. Sung, P.-J.; Fan, T.-Y. 9-O-Deacetylumbraculolide A, a new diterpenoid from the gorgonian Junceella fragilis. Heterocycles 2003, 60, 1199-1202.

14. Sung, P.-J.; Fan, T.-Y.; Fang, L.-S.; Wu, S.-L.; Li, J.-J.; Chen, M.-C.; Cheng, Y.-M.; Wang, G.-H. Briarane derivatives from the gorgonian coral Junceella fragilis. Chem. Pharm. Bull. 2003, 51, 1429-1431.

15. Sung, P.-J.; Lin, M.-R.; Fang, L.-S. Briarane diterpenoids from the Formosan gorgonian coral Junceella fragilis. Chem. Pharm. Bull. 2004, 52, 1504-1506.

16. Sheu, J.-H.; Chen, Y.-P.; Hwang, T.-L.; Chiang, M.Y.; Fang, L.-S.; Sung, P.-J. Junceellolides J-L, 11,20-epoxybriaranes from the gorgonian coral Junceella fragilis. J. Nat. Prod. 2006, 69, 269-273.

17. Sung, P.-J.; Lin, M.-R.; Chen, W.-C.; Fang, L.-S.; Lu, C.-K.; Sheu, J.-H. Fragilide A, a novel diterpenoid from Junceella fragilis. Bull. Chem. Soc. Jpn. 2004, 77, 1229-1230.

18. Sung, P.-J.; Chen, Y.-P.; Su, Y.-M.; Hwang, T.-L.; Hu, W.-P.; Fan, T.-Y.; Wang, W.-H. Fragilide B: A novel briarane-type diterpenoid with a s-cis diene moiety. Bull. Chem. Soc. Jpn. 2007, 80, 1205-1207.

19. Sung, P.-J.; Lin, M.-R.; Su, Y.-D.; Chiang, M.Y.; Hu, W.-P.; Su, J.-H.; Cheng, M.-C.; Hwang, T.-L.; Sheu, J.-H. New briaranes from the octocorals Briareum excavatum (Briareidae) and Junceella fragilis (Ellisellidae). Tetrahedron 2008, 64, 2596-2604.

20. Sung, P.-J.; Pai, C.-H.; Su, Y.-D.; Hwang, T.-L.; Kuo, F.-W.; Fan, T.-Y.; Li, J.-J. New 8-hydroxybriarane diterpenoids from the gorgonians Junceella juncea and Junceella fragilis (Ellisellidae). Tetrahedron 2008, 64, 4224-4232.

21. Sung, P.-J.; Li, G.-Y.; Chen, Y.-P.; Huang, I-C.; Chen, B.-Y.; Wang, S.-H.; Huang, S.-K. Fragilide E, a novel chlorinated 20-acetoxybriarane from the gorgonian coral Junceella fragilis. Chem. Lett. 2009, 38, 454-455. 
22. Sung, P.-J.; Wang, S.-H.; Chiang, M.Y.; Su, Y.-D.; Chang, Y.-C.; Hu, W.-P.; Tai, C.-Y.; Liu, C.-Y. Discovery of new chlorinated briaranes from Junceella fragilis. Bull. Chem. Soc. Jpn. 2009, 82, 1426-1432.

23. Sung, P.-J.; Wang, S.-H.; Chang, Y.-C.; Chen, Y.-H.; Lin, M.-R.; Huang, I-C.; Chen, J.-J.; Li, J.-J.; Kung, T.-H.; Fang, L.-S.; Wang, W.-H.; Weng, C.-F. New briarane-related diterpenoids from the sea whip gorgonian coral Junceella fragilis (Ellisellidae). Bull. Chem. Soc. Jpn. 2010, 83, 1074-1078.

24. Wang, S.-H.; Chang, Y.-C.; Chiang, M.Y.; Chen, Y.-H.; Hwang, T.-L.; Weng, C.-F.; Sung, P.-J. Chlorinated briarane diterpenoids from the sea whip gorgonian corals Junceella fragilis and Ellisella robusta (Ellisellidae). Chem. Pharm. Bull. 2010, 58, 928-933.

25. Shen, Y.-C.; Chen, Y.-H.; Hwang, T.-L.; Guh, J.-H.; Khalil, A.T. Four new briarane diterpenoids from the gorgonian coral Junceella fragilis. Helv. Chim. Acta 2007, 90, 1391-1398.

26. Liaw, C.-C.; Shen, Y.-C.; Lin, Y.-S.; Hwang, T.-L.; Kuo, Y.-H.; Khalil, A.T. Frajunolides E-K, briarane diterpenes from Junceella fragilis. J. Nat. Prod. 2008, 71, 1551-1556.

27. Liaw, C.-C.; Kuo, Y.-H.; Lin, Y.-S.; Hwang, T.-L.; Shen, Y.-C. Frajunolides L-O, four new 8-hydroxybriarane diterpenoids from the gorgonian Junceella fragilis. Mar. Drugs 2011, 9, 1477-1486.

28. Sung, P.-J.; Fan, T.-Y.; Chen, M.-C.; Fang, L.-S.; Lin, M.-R.; Chang, P.-C. Junceellin and praelolide, two briaranes from the gorgonian corals Junceella fragilis and Junceella juncea (Ellisellidae). Biochem. Syst. Ecol. 2004, 32, 111-113.

29. The briaranes $(-)-11 \beta, 20 \beta$-epoxy-4-deacetoxyjunceellolide D and (+)-11 $\beta, 20 \beta$-epoxyjunceellolide D

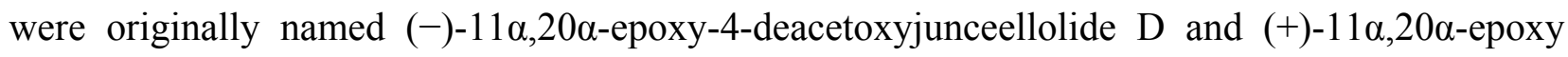
junceellolide $\mathrm{D}$. The stereochemistry of the 11,20-epoxy groups in these two compounds was revised to a $\beta$-orientation, and these briaranes should be renamed (-)-11 $\beta, 20 \beta$-epoxy-4-deacetoxy junceellolide D and (+)-11 $\beta, 20 \beta$-epoxyjunceellolide D, respectively.

30. Sung, P.-J.; Fang, L.-S.; Chen, Y.-P.; Chen, W.-C.; Hu, W.-P.; Ho, C.-L.; Yu, S.-C. 5 $\beta-S t e r o i d s$ from the gorgonian coral Junceella fragilis (Ellisellidae). Biochem. Syst. Ecol. 2006, 34, 64-70.

31. Su, Y.-M.; Fang, T.-Y.; Sung, P.-J. 11,20-Epoxybriaranes from the gorgonian coral Ellisella robusta (Ellisellidae). Nat. Prod. Res. 2007, 21, 1085-1090.

32. Walker, T.A.; Bull, G.D. A newly discovered method of reproduction in gorgonian coral. Mar. Ecol. Prog. Ser. 1983, 12, 137-143.

33. In the in vitro anti-inflammatory bioassay, the inhibitory effects on the generation of superoxide anions and the release of elastase by activated neutrophils were used as indicators. For significant activity of pure compounds, an inhibition rate $\geq 40 \%$ is required (inhibition rate $\leq 10 \%$, not active, $20 \% \geq$ inhibition rate $\geq 10 \%$, weakly anti-inflammatory; $40 \% \geq$ inhibition rate $\geq 20 \%$, modestly anti-inflammatory).

34. Qi, S.-H.; Zhang, S.; Xiao, Z.-H.; Huang, J.-S.; Wu, J.; Li, Q.-X. Study on the chemical constituents of the South China Sea gorgonian Junceella juncea. Chem. Pharm. Bull. 2004, 52, 1476-1478.

35. Qi, S.; Zhang, S.; Huang, J.; Xiao, Z.; Wu, J.; Li, Q. Complete ${ }^{1} \mathrm{H}$ and ${ }^{13} \mathrm{C}$ NMR assignments of four new steroidal glycosides from a gorgonian coral Junceella juncea. Magn. Reson. Chem. 2005, 43, 266-268. 
36. Qi, S.-H.; Zhang, S.; Huang, H.; Xiao, Z.-H.; Huang, J.-S.; Li, Q.-X. New briaranes from the South China Sea gorgonian Junceella juncea. J. Nat. Prod. 2004, 67, 1907-1910.

37. Qi, S.-H.; Zhang, S.; Qian, P.-Y.; Xiao, Z.-H.; Li, M.-Y. Ten new antifouling briarane diterpenoids from the South China Sea gorgonian Junceella juncea. Tetrahedron 2006, 62, 9123-9130.

38. Qi, S.-H.; Zhang, S.; Qian, P.-Y.; Xu, H.-H. Antifeedant and antifouling briaranes from the South China Sea gorgonian Junceella juncea. Chem. Nat. Comp. 2009, 45, 49-54.

39. Sastry, V.G.; Sastry, A.V.S.; Kumar, K.E.; Satyanarayana, S. Chemical examination and biological evaluation of some marine coelenterates of the Indian Ocean. Int. J. Chem. Sci. 2008, 6, 1291-1298.

40. Anjaneyulu, A.S.R.; Rao, V.L.; Sastry, V.G.; Venugopal, M.J.R.V.; Schmitz, F.J. Juncins I-M, five new briarane diterpenoids from the Indian Ocean gorgonian Junceella juncea Pallas. J. Nat. Prod. 2003, 66, 507-510.

41. Krishna, N.; Muralidhar, P.; Kumar, M.M.K.; Rao, D.V.; Rao, C.H.B. Juncenolide B, a new briarane diterpene from the gorgonian Junceella juncea of the Indian Ocean. Asian J. Chem. 2003, 15, 344-348.

42. Krishna, N.; Muralidhar, P.; Kumar, M.M.K.; Rao, D.V.; Rao, C.H.B. A new sphingolipid from the gorgonian Junceella juncea of the Indian Ocean. Nat. Prod. Res. 2004, 18, 551-555.

43. Shen, Y.-C.; Lin, Y.-C.; Huang, Y.-L. Juncenolide E, a new briarane from Taiwanese gorgonian Junceella juncea. J. Chin. Chem. Soc. 2003, 50, 1267-1270.

44. Lin, Y.-C.; Huang, Y.-L.; Khalil, A.T.; Chen, M.-H.; Shen, Y.-C. Juncenolides F and G, two new briarane diterpenoids from Taiwanese gorgonian Junceella juncea. Chem. Pharm. Bull. 2005, 53, 128-130.

45. Wang, S.-S.; Chen, Y.-H.; Chang, J.-Y.; Hwang, T.-L.; Chen, C.-H.; Khalil, A.T.; Shen, Y.-C. Juncenolides $\mathrm{H}-\mathrm{K}$, new briarane diterpenoids from Junceella juncea. Helv. Chim. Acta 2009, 92, 2092-2100.

46. Sung, P.-J.; Fan, T.-Y.; Fang, L.-S.; Sheu, J.-H.; Wu, S.-L.; Wang, G.-H.; Lin, M.-R. Juncin N, a new briarane-type diterpenoid from the gorgonian coral Junceella juncea. Heterocycles 2003, 61, $587-592$.

47. Sung, P.-J.; Pai, C.-H.; Hwang, T.-L.; Fan, T.-Y.; Su, J.-H.; Chen, J.-J.; Fang, L.-S.; Wang, W.-H.; Sheu, J.-H. Junceols D-H, new polyoxygenated briaranes from sea whip gorgonian coral Junceella juncea (Ellisellidae). Chem. Pharm. Bull. 2008, 56, 1276-1281.

48. Sung, P.-J.; Sheu, J.-H.; Xu, J.-P. Survey of briarane-type diterpenoids of marine origin. Heterocycles 2002, 57, 535-579.

49. Sung, P.-J.; Chang, P.-C.; Fang, L.-S.; Sheu, J.-H.; Chen, W.-C.; Chen, Y.-P.; Lin, M.-R. Survey of briarane-related diterpenoids-Part II. Heterocycles 2005, 65, 195-204.

50. Sung, P.-J.; Sheu, J.-H.; Wang, W.-H.; Fang, L.-S.; Chung, H.-M.; Pai, C.-H.; Su, Y.-D.; Tsai, W.-T.; Chen, B.-Y.; Lin, M.-R.; Li, G.-Y. Survey of briarane-type diterpenoids-Part III. Heterocycles 2008, 75, 2627-2648.

51. Sung, P.-J.; Su, J.-H.; Wang, W.-H.; Sheu, J.-H.; Fang, L.-S.; Wu, Y.-C.; Chen, Y.-H.; Chung, H.-M.; Su, Y.-D.; Chang, Y.-C. Survey of briarane-type diterpenoids-Part IV. Heterocycles 2011, 83, 1241-1258. 
52. Harper, M.K.; Bugni, T.S.; Copp, B.R.; James, R.D.; Lindsay, B.S.; Richardson, A.D.; Schnabel, P.C.; Tasdemir, D.; VanWagoner, R.M.; Verbitski, S.M.; Ireland, C.M. Introduction to the Chemical Ecology of Marine Natural Products. In Marine Chemical Ecology; McClintock, J.B., Baker, B.J., Eds.; CRC Press: Washington, DC, USA, 2001; pp. 3-69.

(C) 2011 by the authors; licensee MDPI, Basel, Switzerland. This article is an open access article distributed under the terms and conditions of the Creative Commons Attribution license (http://creativecommons.org/licenses/by/3.0/). 